\title{
Learning How to Teach English in Elementary School: The Role of Reflective Teaching in Training Elementary School Teachers
}

\author{
Xiaoyang Shu \\ Teaching Center, Zhejiang Radio \& TV University, Hangzhou, China \\ Email: sxy327love@126.com
}

How to cite this paper: Shu, X.Y. (2017) Learning How to Teach English in Elementary School: The Role of Reflective Teaching in Training Elementary School Teachers. Open Access Library Journal, 4: e3496. https://doi.org/10.4236/oalib.1103496

Received: March 6, 2017

Accepted: May 13, 2017

Published: May 16, 2017

Copyright (c) 2017 by author and Open Access Library Inc.

This work is licensed under the Creative Commons Attribution International License (CC BY 4.0).

http://creativecommons.org/licenses/by/4.0/ (c) (i) Open Access

\begin{abstract}
Adopting a popular research method-a quality research arisen in the field of social science research, the paper regards four trainee teachers as the research object and reports on how four trainee teachers responded to a short introductory teacher training program (the training program for elementary school English teachers in Yushan county in Jiangxi Province) which mainly focuses on practical teaching skills. With this action research, the research gives an account of how trainee teachers reflect on their learning, how their ideas and beliefs about teaching develop during the program and how the tutors reflect on their teaching. In summary, reflective teaching fosters professional growth and development, critical thinking, self-assessment, and self-directed learning. It promotes the development of new knowledge, leads to broader understanding and creates greater self-awareness. It facilitates selecting from many ideas, helps challenge one's current conceptions of teaching and learning, and assists in identifying how these affect classroom decision-making. Therefore, reflective teaching, with school's involvement, is an invaluable tool in facilitating life-long learning and professional growth.
\end{abstract}

\section{Subject Areas}

Education

\section{Keywords}

Reflective Teacher, Reflective Teaching, Action Research,

Professional Development

\section{Introduction}

In language teaching today, owing to the accelerating pace of change and a 
growing awareness of the principal role of education in social and economic development, Ministry of Education has put forward teaching English in elementary school since the Autumn of 2001. It is clear that there exists many problems in elementary school English teaching, such as the teachers' teaching notion, teaching materials, teaching methods and their low ability to reach the demands of new curriculum, so heavy professional demands are placed on the individual elementary school teacher and training them becomes necessary.

In light of Pennington (1996) [1], the terms reflection and development often recur in recent literature and are useful not merely for changing learners and teachers, but for transforming them from their traditionally limited roles of implementing a curriculum into active agents shaping the future in their mutual contexts. In view of Schon $(1983,1987)$ [2] [3], the most effective method of generating autonomous professional practice is to become reflective practitioners who will continually develop one's own professional expertise by interacting with situations of practice to try to solve problems, thereby gaining an increasingly deep understanding of their subject matter, of themselves as teachers, and of the nature of teaching. At the same time, Dewey is among the first to promote reflection as a means of professional development in teaching. He believed that critical reflection is the most important quality a teacher may have, and that it has much more impact on the quality of schools and instruction than the transmission of teaching techniques (Dewey 1916).

This article addresses the nature of reflective teaching and reports on how four trainee teachers responded to a short introductory teacher training program (the training program for elementary school English teachers in Yushan county) which mainly focuses on practical teaching skills. The aim of the study is to examine how trainee teachers reflect on their learning, how their ideas and beliefs about teaching develop during the program and how the tutors reflect on their teaching. Data for the study are based on the trainee teachers' and the tutors' verbal and written accounts of their learning and teaching experiences.

\section{Methods}

\subsection{Participants and Setting}

This study aims to investigate how the tutors' reflective teaching influences the trainee teacher's self-reflections on their own teaching experiences and how their ideas and beliefs about teaching development during the training program.

The majority of trainee teachers and tutors are female, and they were heterogeneous in their backgrounds in terms of age and teaching experiences. For detailed descriptions in this article, the four trainee teachers and two tutors formed the focus of the study, and will be referred to as teachers A, B, C, D and tutors E and $\mathrm{F}$. They are considered to be a reasonable representation of members of the course. Teacher A has been trained ten years ago as a secondary English teacher in her home county, who has had a variety of teaching experiences at the secondary levels. Teacher B is a novice teacher, who has just graduated from Shangrao Normal School. She has limited experiences and has no solid professional 
knowledge as a primary English teacher. Both of them belong to Class One. The background of Teacher $\mathrm{C}$, including age and teaching experiences, is similar to Teacher A, and the background of Teacher D is similar to Teacher B. But Teacher $\mathrm{C}$ and Teacher D belong to Class Two. Tutor $\mathrm{E}$ is the teacher of Class One, who has two years' experience as a tutor in this training program, and Teacher F, the teacher of Class Two, a new graduate from Jiangxi Normal University, who has tutored secondary and adult students.

This training program for elementary English teachers focuses on practical rather than academic aspects of teaching. The syllabus covers practical ability in classroom management and lesson planning and developing the skills of reading, listening, speaking and writing. Tutor $\mathrm{E}$ and Tutor $\mathrm{F}$ teach pedagogy of two classes.

\subsection{Structure of the Curriculum}

\section{Period one}

Period one is scheduled with two weeks of introduction of pedagogical knowledge, with attention to planning, teaching and analyzing teaching materials. Also curriculum design is considered, with emphasis on critical use of textbooks and materials development.

\section{Period two}

Period two focuses mainly on attending some primary teachers' and famous teachers' lectures, which lasts one week. The trainee teachers are trained with skills in observation, analysis, and evaluation of these lectures. These skills are essential prerequisites for these teachers' teaching practice in their own schools.

\section{Period three}

Period three deals with areas that support the general progress of trainee teachers. Alongside the further acquisition of learner knowledge and application of pedagogical knowledge and skills, each trainee teacher is demanded to conduct the design of a lesson as the final assignment.

\subsection{Data Collection}

Data are collected throughout the year, both during the training period and when the trainee teachers are in their respective schools for teaching practice. The data can be organized into two sets:

1. Trainee teachers' performance during the training periods. It focuses on how two tutors' different teaching notions influence these trainee teachers. Also the final assignment-the design of a lesson-is designed to see whether the trainee teachers could expand learner knowledge and apply the pedagogical knowledge and skills to which they had been initially exposed in the course.

2. Trainee teachers' performance and minds during their school experience. In contrast to the first data set, this data derived from their written and oral reports after they went back to their own schools. Through the training program, we can see whether what the trainee teachers learnt can influence their teaching notions. 


\subsection{Data Analysis}

In analyzing the data, we make efforts to identify concepts that can be used to characterize the recurring issues. To achieve it, the oral and written reports are carefully examined in order to understand what is discussed. From this analysis, the following issues emerge: trainee teachers' performance during the training periods, trainee teachers' performance and minds during their school experience. These two issues form the focus of our analysis. In the remainder of this part, concerns that are raised by the trainee teachers in their oral and written reports of their teaching experiences are discussed.

\section{Results and Discussion}

This part presents an analysis of the influence of the tutors' different teaching notion on each trainee teacher in the course of learning pedagogy. It is based on individual descriptions. Four teachers are the reasonable representation of members.

\section{Trainee teachers' performance during the training periods}

The results for this section are derived from the oral and written accounts of student teachers and tutors. Findings are reported in temporal sequence, that is to say, three periods of the curriculum.

The first period

It is expected that the state of motivation trainee teachers bring to the training program can influence how they learn and develop themselves. All four subjects are motivated learners. Being a secondary school teacher for ten years, Teacher $\mathrm{A}$ and Teacher $\mathrm{C}$ are chosen to be a backbone of elementary English teaching and are assigned to a primary school in a county. Therefore, they need further education due to the differences between primary English teaching and secondary English teaching. In contrast to them, Teacher B and Teacher D are novice teachers, so they find teaching enjoyable, but are sometimes frustrated by inadequate professional knowledge and limited teaching experience. Despite differences in past experience, all four-trainee teachers are committed to this training program and view the full-time program as a solid ground for their career development.

Tutor F is a novice teacher and has no teaching experience. She only regards cramming the trainee teachers some basic theories about pedagogy, such as communicative teaching approach, how to develop the students' listening, reading, speaking and writing skills, and how to prepare for a lesson, as a perfect teaching. Teacher $\mathrm{C}$ has ten years' teaching experience, paying more attention to the practical specific skills taught by the tutor. The following extract from her oral report illustrates her minds:

I am a middle school teacher, having acquired the professional knowledge required by primary school English teachers. Since English education in middle school is rather different from that in primary school, I want to gain a complete knowledge of some specific strategies that make the students interested in English. 
Teacher D narrowly focuses on pedagogical knowledge but the professional knowledge. The following can reflect her minds:

I just graduated from Normal University, but I always feel I am poor in English, so I am worried about I cannot be an excellent English teacher in primary school. Therefore, I just want to acquire some professional knowledge, including the abilities in listening, speaking, reading and writing.

Tutor $\mathrm{E}$ is an experienced teacher. She knows the significance of reflective teaching (that is to say, letting the trainee teachers realize the values of reflection on themselves and their students in teaching practice) in the course of introduction of pedagogical knowledge. Her teaching journal can illustrate her teaching notion:

In the last training project, I taught pedagogy. That is the first time I taught this course with little teaching experience. I just taught trainee teachers some specific teaching methods, finding my classroom mechanical scripted. After having made some improvements in each aspect for a year, I have realized the importance of reflective teaching. In a word, I know we should teach the trainee teachers not only pedagogy, but making them know how to reflect on themselves and their students.

Alongside Tutor E's experiences in last year's training program and in her own teaching practice, she characteristically engaged in some general reflections which related to her past and elevated her to an overview of herself as a reflective tutor. In her class, Teacher A is a teacher at secondary school levels. Therefore, initially she expressed her satisfaction with her performance as a secondary English teacher, but owing to the differences between the elementary English teaching and secondary English teaching and demands on her to become a backbone in a elementary school, she sees the training program as well timed to keep her from possible burnout. Through the training program, she realizes her own limitations, knowing to take the students' factors into consideration. The following extract from her written report can illustrate it:

Before, I just paid attention to improving the students abilities in listening, speaking, reading and writing, so as to help them pass the examination. But after two weeks training, I know we should not only focus on how to improve these strategies, but also teach them how to reflect on themselves in teaching, for example why you choose to teach English, how to teach English, why students need to learn English and how they learn English. Besides, the teacher always requires us to write a journal after a class period, and make a preparation for a lesson before having a discussion with other trainee teachers.

Teacher B is a new graduate from Normal School, whose background is similar to Teacher D. However, due to two tutors' different teaching notions, two different teachers' ideas are quite different. Initially Teacher B only sees teaching as a job that demands a lot of preparation and knowledge of the learning context, about which she is not so skillful. Later, she begins to know the role of solid professional knowledge in teaching, but also realizes the importance of constantly asking herself "how do I do it effectively?" during teaching and learning: 
I just graduated from a Normal University, full of interest in teaching. Before, I held that only teaching students how to read and write is of great importance, but now I know so are the techniques of how to teach reading, writing and etc. Besides, we should reflect on ourselves continually, for example, where can I improve my teaching? Why were the students willing to listen to me in class today? With the guidance of the teacher, I learn to write the journal every day.

The second period

In this period, Tutor E always arranged a forum in which the trainee teachers could air their voices after attending those famous teachers' lectures. She convinced the trainee teachers of the significance and competence in becoming a helpful partner to other peer trainee teachers. The following extracts are derived from Teacher A's journals:

I had thought it was the students who should be responsible for their failure in English because they are lazy or childish. But after listening to the lectures delivered by two teachers from Hei Longjiang EEC, I find that it is the teachers who can arouse the students' interest in English, and make them focus on classes. But why couldn't I deal with it when I was in Middle School? Actually, I also spent much time making preparation for the classes.

(August 5, 2003)

Today the teacher organized a seminar where the trainee students would talk about their feelings about this week's lectures. Everyone talked about what they had thought. I had thought I am a middle school teacher, better than other teachers. But finally, I found everybody had their own ideas about teaching, which could help me a lot. Therefore, I should always discuss with other teachers.

(August 10, 2003)

From Teacher B's written report, we can find that she is also persuaded to accept that dialogue is the highest form of teaching (Plato). Dialogue allows trainee students to be aware of what they share in common, as well as the uniqueness of each of them as individuals; therefore, we can promote reflection abilities through dialogue in form of seminar instruction, peer collaboration and so on. The following is from Teacher B's written report:

It is quite useful for us to exchange the ideas about the teachers lectures. The peer trainee teachers can help me find out some weak points and strong points in these teachers' lectures and lessons. I hold that after I finish this training program and begin to have lessons, in my school, we can also arrange a seminar, in which we discuss how to prepare the lessons and so on. I admire Tutor E can arrange this forum, which helps me too much.

(August 8, 2004)

Tutor $\mathrm{F}$ has no idea of asking the trainee teachers to think about the teachers' lectures. Teacher C and Teacher D only note each specific step of each teacher's lesson. Even if sometimes they have some opinions about these lectures, they don't write them down and have no idea of exchanging them with peer trainee teachers; therefore, in their minds, quickly there is nothing. 


\section{The third period}

In this period, Tutor $\mathrm{E}$ also held a forum encouraging reflection on the design of each trainee teacher. Most of trainee teachers are satisfied with this activity. This is what Teacher A said: Through this forum, I can appreciate peer trainee teachers' lessons. And they can tell me my strengths and weaknesses in my lessons, which help me a lot. Teacher B held: This is the first time that I presented the design of a lesson. I am a bit nervous. Peer teachers have given me encouragement. But at the same time, they point out my weaknesses (too nervous and too contents in a lesson because the children can't accept it). They even imitate some behavior appearing in my presentation, but I feel encouraged rather than embarrassed. Obviously, trainee teachers in Class one enjoy comments given by peer trainee teachers which can help them do self-reflection other than only scores they get in final assignment.

While Tutor F only collects the assignments of trainee teachers and give them scores according to her individual idea. Trainee teachers in Class two only know their respective score, but don't know why they get this score. They also don't know strong points and weak points of their assignment.

\section{Trainee teachers' performance and minds during their school experience}

After nearly four weeks of training, trainee teachers went back to their assigned schools. Teacher A is assigned to a school named Yifu elementary school in Yushan County. With interview, the author knows that she insists on writing journals and arranges a seminar each week. The following is from her journal:

Even if there are only three English teachers in my school, I plan to hold a seminar each week and will ask the other two teachers to attend my class and give me suggestions honestly.

(Sep. 10, 2003)

Today I asked the children to write some words that they can read and recite, but I found it difficult for them to write them down. Why?

(Sep. 25, 2003)

After a week's observation, I find that I design limited activities for practicing writing. These days, I design more activities for writing, which seems effective.

(Oct. 9, 2003)

Teacher B is assigned to a school called Baiyun primary school in Yushan countryside. The teaching conditions in countryside school are clearly worse than those in Yifu primary school---a school in county. However, she is energetic, and makes efforts to arouse the children's interests. The following is from her journal:

Today I planned to deliver the content of my lesson through a game, but since the children were unwilling to cooperate with me, I just finished the lesson reluctantly. I thought there was something wrong with my lesson; then I should try to find the reason in the later classes.

(Sep. 20, 2003)

Her analysis led her to see the problem as originating with both the teacher and the students. She realized that she couldn't attract the children's eyes, so she 
wanted to solve it in the following classes. We can't deny that Tutor E's instruction in the training program contributes to her behavior.

Teacher $\mathrm{C}$ is assigned to a school called Jinshan primary school in the county. She is a responsible teacher and tries her best to let the children learn the contents of each lesson. Teacher D is assigned to a countryside school named Wencheng primary school. Because both of them are not accustomed to self-reflections, when they meet problems during dealing with lessons, they don't know that they can solve them through peer collaboration and class observation and so on.

\section{Conclusions and Implications}

This part reports on the role of reflective teaching in training elementary school teachers. Dewey (1933) [4] suggested three conditions for reflective teaching: open-mindedness, responsibility and wholeheartedness. And Sun \& Han (2003) [5] argued that an individual practitioner, together with the people in the school setting such as peers, pupils and principals, constructs reflective practice. Therefore, it is just like what Zeichner and Liston [6] put forward in 1996: reflective teaching is for teachers to think about the origins, purposes and consequences of their actions, as well as the material and ideological constraints and encouragements embedded in the classroom, and social contexts in which they live. Four subjects in our study can have these conditions, but they don't have many chances to get to the theories such as reflective teaching and teacher development. Through training program, Tutor $\mathrm{E}$ introduced reflective teaching to a certain degree and taught trainee teachers pedagogy through reflective teaching as an example. We can't say that Teacher A and Teacher B have a clear idea about reflective teaching; however, they are really influenced by it. They get used to writing journals, solving problems through the form of seminar instructions and so on [7]. Anyway, even if the present training program pays more attention to reflective teaching, and the trainee teachers agree that self-reflection is helpful in teaching, the effects of reflection is not ideal because the teachers' self-reflections are always short-term and no systematic and scientific.

While echoing many scholars' argument that reflection is crucial, cultural and social, this study suggests the need to involve trainer teachers and schools. The contribution of trainer teachers and school principals is vital to teacher development. Teacher B and Teacher D work in a countryside school. It is obvious that they have fewer chances to get to some new teaching notions. Therefore, it is necessary for school principals to explore ways to support their further training beyond initial training. As to trainer teachers, they also should be a reflective teacher because what they teach and do will influence trainee teachers.

In summary, reflective teaching fosters professional growth and development, critical thinking [8], self-assessment, and self-directed learning. It promotes the development of new knowledge, leads to broader understanding and creates greater self-awareness (Osterman, 1990) [9]. It facilitates selecting from many ideas, helps challenge one's current conceptions of teaching and learning, and 
assists in identifying how these affect classroom decision-making. Therefore, reflective teaching is an invaluable tool in facilitating life-long learning and professional growth.

\section{Acknowledgements}

My thanks to the anonymous reviewers for reading and commenting on the early drafts of this article.

The project is supported by the Program for Research on Educational Technology of China (Grant No. 146241759), the Foundation of Distance Education: Development and Innovation (Grant No. 2014ZX02), Social Science Project of Hangzhou in 2017 (Grant No. M17JC021), High-quality Course Project-Essentials of Translation.

\section{References}

[1] Pennington, M.C. (1996) The "Cognitive-Affective Filter" in Teacher Development: Transmission-Based and Interpretation-Based Schemas for Change. System, 24, 337-350. https://doi.org/10.1016/0346-251X(96)00026-7

[2] Schon, D. (1983) The Reflective Practitioner: How Professionals Think in Action. Temple Smith, London.

[3] Schon, D. (1987) Educating the Reflective Practitioner: Towards a New Design for Teaching and Learning in the Profession. Jossey-Vass, San Francisco.

[4] Dewey, J. (1933) How We Think. Health \& Co., New York.

[5] Sun, L. and Han, Y.P. (2003) Action Research: The Bridge between Teaching Theory, Teaching Practice and Teaching Research. Foreign Language Teaching in Schools, 1 .

[6] Zeichner, K.M. and Liston, D.P. (1996) Reflective Teaching: An Introduction. Lawrence Erlbaum Associates, Mahwah, NJ.

[7] Richards, J. and Lockhart, C. (1994) Reflective Teaching in Second Language Classrooms. Foreign Language Teaching and Research Press, Cambridge University Press. https://doi.org/10.1017/CBO9780511667169

[8] Brookfield, S. (1995) Becoming a Critically Reflective Teacher. Jossey-Bass Inc., San Francisco.

[9] Osterman, K.F. (1990) Reflective Practice: A New Agenda for Education. Education and Urban Society, 22, 133-152. https://doi.org/10.1177/0013124590022002002 
Submit or recommend next manuscript to OALib Journal and we will provide best service for you:

- Publication frequency: Monthly

- 9 subject areas of science, technology and medicine

- Fair and rigorous peer-review system

- Fast publication process

- Article promotion in various social networking sites (LinkedIn, Facebook, Twitter, etc.)

- Maximum dissemination of your research work

Submit Your Paper Online: Click Here to Submit

Or Contact service@oalib.com 